\title{
Correction to: Bringing corporate governance into internalization theory: State ownership and foreign entry strategies
}

Birgitte Grøgaard', Asmund Rygh ${ }^{2}$ and Gabriel R. G. Benito ${ }^{1}$

${ }^{1}$ BI Norwegian Business School, Nydalsveien 37, 0484 Oslo, Norway; ${ }^{2}$ Alliance Manchester Business School, The University of Manchester, Manchester M15 6PB, UK

Correspondence:

B Grøgaard, BI Norwegian Business School, Nydalsveien 37, 0484 Oslo, Norway

e-mail: birgitte.grogaard@bi.no
The original article can be found online at https://doi.org/10.1057/s41267-019-00237-5.

Online publication date: 21 January 2020
Journal of International Business Studies (2020) 51, | 35 |-| 352.

https://doi.org/ 10.1057/s41267-020-00302-4

The online version of this article is available Open Access

\section{CORRECTION TO: JOURNAL OF INTERNATIONAL BUSINESS STUDIES (2019) \\ https://doi.org/10.1057/s41267-019-00237-5}

The article "Bringing corporate governance into internalization theory: State ownership and foreign entry strategies," written by Birgitte Grøgaard, Asmund Rygh, and Gabriel R. G. Benito, was originally published electronically on the publisher's internet portal (currently SpringerLink) on 15 May 2019 without open access.

With the author(s)' decision to opt for Open Choice, the copyright of the article changed on January 2020 to (c) The Author(s), and the article is forthwith distributed under the terms of the Creative Commons Attribution 4.0 International License (http://creativecommons.org/licenses/by/4.0/), which permits use, duplication, adaptation, distribution, and reproduction in any medium or format, as long as you give appropriate credit to the original author(s) and the source, provide a link to the Creative Commons license and indicate if changes were made.

Open Access This article is licensed under a Creative Commons Attribution 4.0 International License, which permits use, sharing, adaptation, distribution and reproduction in any medium or format, as long as you give appropriate credit to the original author(s) and the source, provide a link to the Creative Commons licence, and indicate if changes were made. The images or other third party material in this article are included in the article's Creative Commons licence, unless indicated otherwise in a credit line to the material. If material is not included in the article's Creative Commons licence and your intended use is not permitted by statutory regulation or exceeds the permitted use, you will need to obtain permission directly from the copyright holder. To view a 
copy of this licence, visit http://creativecommons.org/licenses/by/ $4.0 /$.

Publisher's Note Springer Nature remains neutral with regard to jurisdictional claims in published maps and institutional affiliations. 